\title{
Intention and Usage of Human Resource Information Systems among Ghanaian Human Resource Managers
}

\author{
Ebenezer Ankrah $^{1} \&$ Evans Sokro ${ }^{2}$ \\ ${ }^{1}$ School of Applied Sciences, Information Technology Department, Central University College, Ghana \\ ${ }^{2}$ Federation Business School, Federation University, Australia \\ Correspondence: Ebenezer Ankrah, School of Applied Sciences, Information Technology Department, Central \\ University College, P.O. Box 2305 Tema, Ghana. Tel: 233-244-657-044. E-mail: ebankrah@yahoo.com
}

Received: December 2, 2015

Accepted: December 16, 2015

Online Published: January 23, 2016

doi:10.5539/ijbm.v11n2p241

URL: http://dx.doi.org/10.5539/ijbm.v11n2p241

\begin{abstract}
The purpose of this study is to investigate the intentions and usage of human resource information systems (HRIS) among Ghanaian HR managers and practitioners. In today's global networking era, information technology has become an integral part of human resource management. This is because the increasing pressure to support strategic goals and the greater focus on shareholder value has led to changes in both job content and expectations of Human Resource professionals. Hence, the use of Human Resource Information System has been used by HR professionals to become strategic managers. Survey methodology was adopted to obtain data from HR managers and practitioners in Ghanaian companies. A net-targeted sample of 175 respondents produced 100 usable questionnaires for analysis. The study results revealed that information technology (IT) has assisted "organizations to deliver state-of-the art HR services, and reduced operational costs of companies, regardless of the size of the firm". Advances in IT helps in resolving many of the challenges of HRM such as attracting, retaining, motivating employees, meeting the demands for a more strategic HR function, and managing the "human element" of technological change. Furthermore, effective HRIS has a direct positive influence on organizational performance.
\end{abstract}

Keywords: information systems, human resource information systems, human resource management

\section{Introduction}

In today's knowledge-based economy, the success of an organization depends largely on the performance of its human resources. As a consequence, organizations nowadays are becoming increasingly dependent on human resource information system (HRIS) in order to increase the effectiveness of their most valued assets-the human resources (Lippert \& Swiercz, 2005; Toshani, Jerram, \& Gerrard, 2010; Toshani, Jerram, \& Hill, 2011). Human resource information system is briefly defined by Hendrickson (2003) as an integrated system used to gather, store and analyze information regarding an organization's human resources. Other researchers view HRIS "as a dynamic database of demographic and performance information about each employee. It comprises of software, hardware and systematic procedure used to acquire, store, manipulate, analyze, retrieve and distribute pertinent information about an organization's human resource" (Lippert \& Swiercz, 2005; Kovach \& Cathcart Jr., 1999; Tannenbaum, 1990 ). It is therefore, any technology that is used to attract, hire, retain and maintain talent, support workforce administration and optimize workforce management (Reddick, 2009; Tannenbaum, 1990). Accordingly, Human resource information systems have become one of the most vital information systems in the market. Typically, human resource management has in recent times shifted its focus on knowledge sharing and strategic workforce analysis and has become a significant contributor to the strategic management of organizations (Rodriguez \& Ventura, 2003). As such, for human resource professionals to become strategic partners with top management, the use of HRIS is crucial (Ankrah \& Sokro, 2012; Lengnick-Hall \& Moritz, 2003).

Kassim, Ramayah, and Kurnia (2012) maitain that a good HRIS is more likely to produce a good human resource decision. They comment further that such a system should be provided to both human resource and line managers to facilitate decision making. In the competitive environment within which contemporary organisations operate. Indeed, strategic value can be derived by HRIS tools that assist with decision-making concerning vital HR functions (Farndale, Scullion, \& Sparrow, 2010). HRIS allows HR functions to become 
more efficient and to provide better information for decision making. The special function of HRIS is to gather, collect and help analyze the data necessary for human resource management department to perform its tasks effectively (Anthony, Kacmar, \& Perrewe, 2002). The HRIS can assist organizations to improve administrative efficiency through faster information processing, improved employee communications, greater information accuracy, lower HR costs and overall HR productivity improvements (Kassim et al., 2012; Wiblen, Grant, \& Dery, 2010). It can also support long range planning with information on equal employment, separations and applicant qualifications and development with information on training programs, salary forecasts, pay budgets and labor/employee relations with information on contract negotiations and employee assistance needs (Al-Shibly, 2011). Primarily, the focus of HRIS in many organizations is on administrative efficiency. Nonetheless, as organizations seek to achieve a competitive edge in the rapidly knowledge-based economy, there is a growing pressure for HR to play a more strategic role in aiding organizations achieve their long term strategic objectives (Sheehan, Holland, \& De Cieri, 2006; Teo et al., 2007). Accordingly, Teo et al. (2007) contend that the growing link between HR and business strategy compels organizations to depend on their HR professionals for innovative programs and practices to nurture a more competitive workforce.

Although, organizations have spent huge sums of money on implementing various information systems, usage among end users remains low especially in developing countries as evident in e-government, e-learning, online stock trading and e-HRM (Lean, Zailani, Ramayah, \& Fernado, 2009; Ramayah, 2010; Ramayah, Rouibah, Muniandy, \& Rangel, 2009; Schaupp, Carter, \& McBride, 2010; Yusoff, Ramayah, \& Ibrahim, 2011). Despite the importance of HRIS for organisations, researchers seem to agree that HRIS adoption remains under researched (Blount \& Castleman, 2009; Henriksen \& Mahnke, 2005) especially in developing countries. The purpose of this study is to find out the intention and usage of HRIS among Ghanaian HR managers and practitioners. The specific objectives are: (1) to find out whether Human Resource practitioners are making use of Human resource information system (HRIS) as they manage their Human Resources (HRs) and (2) examine the relationship between the effective usage of HRIS and organizational performance. This study, thus, provides insight and understanding of HRIS adoption which is necessary given the growing organizational interest in HRIS. The research was guided by the Technology Acceptance Model (TAM).

Human resource is a major input to the success of companies. When employees in an organization are managed effectively and strategically, production could further be maximized. This research will serve as a guide to effective implementation of human resource information systems (HRIS). It would also provide reasonable insight into the effective ways of managing employee matters by the optimum use of HRIS.

\section{Literature Review}

\subsection{Development and Role of HRIS}

Originally, "information about personnel were frequently limited to employee names and addresses and perhaps some employment history, often recorded on note cards" (Kavanagh, Gueutal, \& Tannenbaum, 1990). The earliest automated employee information systems appeared in the 1940s, and all the way through the 1950s were run on sorting and tabulating equipment. In those days the computer system has a very limited purpose, concerned only with monitoring employee records and payroll activities. During the 1960s, personnel departments took little part in the technological advances in computing that were occurring in the accounting and finance sections. This notwithstanding, HRIS has grown in popularity since the 1960s. This is because organizations became more aware of human capital issues and began to develop formal processes for employee selection and development. There was also increasing recognition of the importance of employee morale on firm's overall effectiveness among organizations, hence personnel management was an early candidate for office automation in payroll, benefits administration and other transaction processing applications such as employee record holding (Hendrickson, 2003; Lederer, 1984; Kavanagh et al., 1990; Martinsons, 1994). Consequently, between 1960 and 1980, "HR was integrated into the core business mission and governmental and regulatory reporting requirements for employees especially in corporate America" (Hendrickson, 2003).

Data maintained in an HRIS can be used as a competitive information resource for virtually all core management functions including planning, organizing, monitoring, controlling and leading (Hubbard, Forcht, \& Thomas, 1998). HRIS technology supports strategic planning through the generation of labour force supply and demand forecasts. Also, human resource information system is of a great benefit to both employees and employers. Indeed, as technology integrates with traditionally labor-intensive HR activities, HR professional are seeing improvements in response to time and efficiency.

\subsection{The Usage of HRIS}

Human resource information systems have evolved into "sophisticated information technology solutions 
designed to manage a wide range of human resource data and to provide analytical tools to assist management in HR decision-making" (Hendrickson, 2003). Although HRIS adoption can be challenging, the number of firms investing in HRIS have dramatically increased in recent years (Ashbaugh \& Miranda, 2002; Ball, 2001). Studies acknowledged that the benefits of HRIS included "improved accuracy, the provision of timely and quick access to information and the saving of costs" (Lederer, 1984; Ngai \& Wat, 2006; Tetz, 1973; Wille \& Hammond, 1981). Human resource information systems have been designed to help HR managers to perform different types of duties both routine and higher level and allows HR managers to perform their new demerging roles more professionally and gain better recognition. According to Laudon and Laudon (2002), HRIS are used at three levels of organization as they offer a comprehensive set of functionality, such as training, career pathing and compensation analysis. Human resource practitioners use HRIS to their advantage to enhance faster information processing, greater information accuracy, improved planning and program development, and enhanced employee communications. Ankrah and Sokro (2012) maintain that HRIS enables HR professionals and supervisors to manage complex information entities and to plan HR efficiently.

A number of studies have examined the factors that enhance successful implementation of HRIS. Based on the above literature, the following hypotheses are postulated:

Hypothesis 1: Most Human Resource Managers and Practitioners use Human Resource

Information Systems (HRIS) due to its acclaimed benefits.

Hypothesis 2: Human Resource Managers and Practitioners who use Human Resource

Information Systems (HRIS) perform better than those who do not use HRIS.

\section{Research Methodology}

Considering the nature of this research, a survey research design was deployed. A structured questionnaire was the main instrument used to collect data because it is cost effective and convenience to use as HR managers and employees find it difficult to grant interviews. The target population is HR managers and Practitioners working in the HR department in Ghanaian firms because they are in the best position to throw more light on the intention and usage of HRIS among Ghanaian HR managers. Fifteen organizations were randomly from the capital city of Ghana, Accra due to proximity to the researchers and the willingness of the respondents to participate in the study. A net-targeted sample of 175 respondents from the selected organizations produced 100 usable questionnaires for analysis. The questionnaire was designed to solicit information on the use of HRIS, the types of HRIS, the availability of HRIS and how it impact on performance. The intention and attitude of HR Managers towards HRIS was also examined. The statistical package for social sciences (SPSS) was used for data capturing and analysis due to its ease of use. Simple frequencies and percentages were used to portray the true picture of the data collected as well as test of hypotheses.

\section{Major Findings}

Table 1. Uses of HRIS?

\begin{tabular}{lll}
\hline Response & Frequency & Percent \\
\hline Keep staff records and & 50 & 50.0 \\
Personal details & & \\
Data collection and data management & 30 & 30.0 \\
Paying of staffs and accrue leave days & 10 & 10.0 \\
Retrieve information for reports reasons & 10 & 10.0 \\
Total & 100 & 100.0 \\
\hline
\end{tabular}

Source: Field data, 2015.

From the above table, 50\% representing majority of respondents indicated that HRIS is used for keeping staff records and personal data, $30 \%$ of the respondents reveal they use HRIS for data collection and data management. Paying of staff and accrue leave days and the retrieval of information for reports reasons represents $10 \%$ each. According to Laudon and Laudon (2002) HRIS are used at three levels of organization as they offer a comprehensive set of functionality, such as training, career path and compensation analysis. The use of HRIS has significantly reduced HR cost by automating information and reducing the number of HR employees, and by helping employees to control their own personal information and data, conduct analysis, make decisions and communicate with others without consulting an HR professional (Awuzu \& Desouza, 2003; Ball, 2001). Some of 
the software that the HR departments use are Epicor, Eazy HR, Oracle, Soft HR, Attend HRM, and HR Solution. It is clear that the organizations under study have actually achieved a great deal of success where $60 \%$ of the respondents said the implantation of the HRIS was successful and the remaining $40 \%$ said it was very successful. The result relating to how often they receive training indicate that $8.9 \%$ of the employees receives training quarterly, $22.2 \%$ receives training when necessary, $15.6 \%$ says they go through training yearly, $31.1 \%$ goes through training most often, $17.8 \%$ says twice a year and $4.4 \%$ receives training monthly.

\subsection{Hypotheses Testing}

The chi-square statistic was used to test the hypotheses because the study was testing for goodness of fit.

\subsubsection{Hypothesis One}

Ho: Most Human Resource Managers and Practitioners do not use Human Resource Information Systems (HRIS).

Ha: Most Human Resource Managers and Practitioners use Human Resource Information Systems (HRIS).

Where Ho is the null hypothesis and;

Ha is the alternative hypothesis.

\section{Significance level}

The significance level $(\alpha)$ for this test is 0.05 .

\section{Critical value}

From chi-square distribution table, a significance level of 0.05 with one degree of freedom gives a critical value of 3.841 .

\section{Decision rule}

The researcher cannot accept Ho, if chi-square calculated is greater than 3.841 and conclude that, most Human Resource Managers and Practitioners use Human Resource Information Systems (HRIS) else the researcher will fail to reject Ho and conclude that, most Human Resource Managers and Practitioners do not use Human Resource Information Systems (HRIS).

\section{Test statistic}

The test statistic is a chi-square, $\chi^{2}$ with $(\mathrm{I}-1) *(\mathrm{~J}-1)$ degrees of freedom.

$$
\chi^{2} \text { value }=\sum_{\mathrm{i}=1}^{1} \sum_{\mathrm{j}=1}^{\mathrm{J}} \frac{\left(\mathrm{O}_{\mathrm{ij}}-\mathrm{E}_{\mathrm{ij}}\right)^{2}}{\mathrm{E}_{\mathrm{ij}}} \text { with } \mathrm{df}=(\mathrm{I}-1) *(\mathrm{~J}-1)
$$

Where $\mathbf{O i j}$ are the observed values;

Eij are the expected values and;

df is the degrees of freedom.

Now, the calculated chi-square from Table 2 is as follows;

$$
\begin{aligned}
\chi^{2}= & \frac{(68-59.0)^{2}}{59.0}+\frac{(4-13.0)^{2}}{13.0}+\frac{(14-23.0)^{2}}{23.0}+\frac{(14-5.0)^{2}}{5.0} \\
& =1.3729+6.2308+3.5217+16.2000 \\
& =27.3254
\end{aligned}
$$

\begin{tabular}{|c|c|c|c|c|c|}
\hline \multirow{2}{*}{$N=\mathbf{1 0 0}$} & & & \multicolumn{2}{|c|}{ HRIS Use } & \multirow[b]{2}{*}{ Total } \\
\hline & & & Yes & No & \\
\hline \multirow[t]{4}{*}{ HRIS Availability } & Yes & Count & 68 & 4 & 72 \\
\hline & & Expected Count & 59.0 & 13.0 & 72.0 \\
\hline & No & Count & 14 & 14 & 28 \\
\hline & & Expected Count & 23.0 & 5.0 & 28.0 \\
\hline \multirow[t]{2}{*}{ Total } & & Count & 82 & 18 & 100 \\
\hline & & Expected Count & 82.0 & 18.0 & 100.0 \\
\hline
\end{tabular}

Table 2. Relationship between HRIS availability and HRIS use

$\mathrm{N}=100 ; \mathrm{P}$-Value $=0.000 ; \mathrm{COR}=0.519$. 
The chi-square calculated is equal to 27.3254 and the critical value is equal to 3.841 . Since the chi-square calculated is greater than the critical value, thus, Ho cannot be accepted. Therefore, most Human Resource Managers and Practitioners use Human Resource Information Systems (HRIS). The correlation coefficient between the two variables is 0.519 , indicating that there exists a positive relationship between the availability and use of HRIS which is indeed strong.

\subsubsection{Hypothesis Two}

Ho: Human Resource Managers and Practitioners who use Human Resource Information Systems (HRIS) do not perform better than those who do not use HRIS.

Ha: Human Resource Managers and Practitioners who use Human Resource Information Systems (HRIS) perform better than those who do not use HRIS.

Where Ho is the null hypothesis and

Ha is the alternative hypothesis

\section{Significance level}

The significance level $(\alpha)$ for this test is 0.05 .

\section{Critical value}

From chi-square distribution table, a significance level of 0.05 with two degrees of freedom gives a critical value of 5.991 .

\section{Decision rule}

The researcher cannot accept Ho, if chi-square calculated is greater than 5.991 and conclude that, Human Resource Managers and Practitioners who use Human Resource Information Systems (HRIS) perform better than those who do not use HRIS else the researcher will fail to reject Ho and conclude that, Human Resource Managers and Practitioners who use Human Resource Information Systems (HRIS) do not perform better than those who do not use HRIS.

\section{Test statistic}

The test statistic is a chi-square, $\chi^{2}$ with $(\mathrm{I}-1)^{*}(\mathrm{~J}-1)$ degrees of freedom.

$$
\chi^{2} \text { value }=\sum_{\mathrm{i}=1}^{1} \sum_{\mathrm{j}=1}^{J} \frac{\left(\mathrm{O}_{\mathrm{ij}}-\mathrm{E}_{\mathrm{ij}}\right)^{2}}{\mathrm{E}_{\mathrm{ij}}} \text { with } \mathrm{df}=(\mathrm{I}-1)^{*}(\mathrm{~J}-1)
$$

Where Oij are the observed values;

Eij are the expected values and;

df is the degrees of freedom.

Now the calculated chi-square is as follows from table 1;

$$
\begin{aligned}
\chi^{2}= & \frac{(35-38.1)^{2}}{38.1}+\frac{(13-13.0)^{2}}{13.0}+\frac{(45-41.9)^{2}}{41.9}+\frac{(6-2.9)^{2}}{2.9}+\frac{(1-1.0)^{2}}{1.0}+\frac{(0-3.2)^{2}}{3.2} \\
& =0.2522+0.0000+0.2294+3.3138+0.0000+3.2000 \\
& =6.9954
\end{aligned}
$$

\begin{tabular}{|c|c|c|c|c|c|c|}
\hline \multirow{2}{*}{$N=100$} & & & \multicolumn{3}{|c|}{$\underline{\text { Performance }}$} & \multirow[b]{2}{*}{ Total } \\
\hline & & & Low & Moderate & High & \\
\hline \multirow[t]{4}{*}{ HRIS Use } & Yes & Count & 35 & 13 & 45 & 93 \\
\hline & & Expected Count & 38.1 & 13.0 & 41.9 & 93.0 \\
\hline & No & Count & 6 & 1 & 0 & 7 \\
\hline & & Expected Count & 2.9 & 1.0 & 3.2 & 7.0 \\
\hline \multirow[t]{2}{*}{ Total } & & Count & 41 & 14 & 45 & 100 \\
\hline & & Expected Count & 41.0 & 14.0 & 45.0 & 100.0 \\
\hline
\end{tabular}

Table 3. Relationship between HRIS Use and performance

$\mathrm{N}=100 ; \mathrm{P}$-Value $=0.000 ; \mathrm{COR}=0.266$.

The chi-square calculated is equal to 6.9954 and the critical value is equal to 5.991 . Since the chi-square 
calculated is greater than the critical value, thus, Ho cannot be accepted. Therefore, Human Resource Managers and Practitioners who use Human Resource Information Systems (HRIS) perform better than those who do not use HRIS. The correlation coefficient between the two variables is 0.266 , indicating that there exists a positive relationship between the two variables which is indeed weak. The most obvious impact has been operationalthat is, automating routine activities, alleviating administrative burdens, reducing cost, and improving productivity internal to the HR function itself.

\section{Conclusion}

Over the years, HR Managers have implemented strategic software that reduces cost. Subjecting the hypotheses to a statistical test yielded the following: (1) Most Human Resource Managers and Practitioners use Human Resource Information Systems (HRIS) and (2) Human Resource Managers and Practitioners who use Human Resource Information Systems (HRIS) perform better than those who do not use HRIS.

Ideally, with an appropriate use of HRIS, less people should needed to perform administrative tasks such as record keeping and more time would be made available for HR Managers to assist by providing data on a strategic level. The future for effective use of HRIS worldwide is bright as it creates new paths for human resources and for the organizations that effectively use HRIS. There is a need for managers to provide effective training and regularly update their HRIS in order to outwit their competitors in this throat cutting competitive era in which companies operates. Organizations should carefully select their HRIS products and come to an agreement with the vendor on HRIS features when they invest in HRIS since the cost is very huge and failure of these systems will be a great loss to the organization. For future research, the impact of human resource information systems on organizational performance would be a good venture as well as the study of human resource information systems and its benefits to organizations. This will help to enhance the use of human resource information systems.

\section{References}

Al-Shibly, H. (2011). Human Resource Information Sytems Success Assessment: An Integrative Model. Australian Journal of Basic and Applied Sciences, 5(5), 157-169.

Ankrah, E. (2013). Customer Satisfaction of Electronic Products and Services in Ghanaian Banks. Information and Knowledge Management, 3(1), 7-18.

Ankrah, E., \& Sokro, E. (2012). Human Resource Information System as a Strategic Tool in Human Resource Management. Problems of Management in the 21st Century, 5, 6-15.

Anthony, W., Kacmar, K., \& Perrewe, P. (2002). Human Resource Management: A Strategic Approach (4th ed.). New York, NY: Prentice Hall.

Ashbaugh, S., \& Miranda, R. (2002). Technology for Human Resource Management: Seven Questions and Answers. Public Personnel Management, 31(1), 7-20. http://dx.doi.org/10.1177/009102600203100103

Ball, K. (2001). The Use of Human Resource Information Systems: A Survey. Personnel Review, 30(6), 677-693. http://dx.doi.org/10.1108/EUM0000000005979

Barney, J. (1991). Firm Resources and Sustained Competitive Advantage. Journal of Management, 17(1), 99-120. http://dx.doi.org/10.1177/014920639101700108

Beadles, N., Lowery, C., \& Johns, K. (2005). The Impact of Human Resource Information Systems: An Exploratory Study in the Public Sector. Communications of IIMA, 5(4), 39-46.

Beckers, A., \& Bsat, M. (2002). A DSS Classification Model for Research in Human Resource Information $\begin{array}{llll}\text { Systems. } & \text { Information } & \text { Systems }\end{array}$ http://dx.doi.org/10.1201/1078/43201.19.3.20020601/37169.6

Blount, Y., \& Castleman, T. (2009). The Curious Case of the Missing Employee in Information Systems Research. Proceedings of the 20th Australasian Conference on Information Systems, Monash University, Australia, (pp. 300-310).

Bondarouk, T., \& Ruel, H. (2009). Electronic Human Resource Management: Challenges in the Digital Era. The International Journal of Human Resource Management, 20(3), 505-514. http://dx.doi.org/10.1080/09585190802707235

Broderick, R., \& Boudreau, J. (1992). Human Resource Management, Information Technology and the Competitive Edge. Academy of Management Executive, 6(2), 7-17. http://dx.doi.org/10.5465/AME.1992.4274391 
De Pablos, P. (2004). Human Resource Management Systems and their Role in the Development of Strategic Resources: Empirical Evidence. Journal of European Industrial Training, 28(6), 474-489. http://dx.doi.org/10.1108/03090590410542701

DeSanctis, G. (1986). Human Resource Information Systems: A Current Assessment. MIS Quarterly, 10, 15-26. http://dx.doi.org/10.2307/248875

Farndale, E., Scullion, H., \& Sparrow, P. (2010). The Role of the Corporate HR Function in Global Talent Management. Journal of World Business, 45(2), 161-168. http://dx.doi.org/10.1016/j.jwb.2009.09.012

Haines, V., \& Petit, A. (1997). Conditions for Successful Human Resource Information Systems. Human Resource Management, 36(2), 261-275. http://dx.doi.org/10.1002/(SICI)1099-050X(199722)36:2<261::AID-HRM7>3.0.CO;2-V

Harris, D., \& Desimone, R. (1995). Human Resource Development (4th ed.). TX: Dryden Press.

Hendrickson, A. (2003). Human Resource Information Systems: Backbone Technology of Contemporary Human Resources. Journal of Labour Research, 24(3), 381-394. http://dx.doi.org/10.1007/s12122-003-1002-5

Henriksen, H. Z., \& Mahnke, V. (2005). E-procurement Adoption in the Danish Public Sector. Scandinavian Journal of Information Systems, 17(2), 85-106.

Hubbard, J., Forcht, K., \& Thomas, D. (1998). Human Resource Information Systems: An Overview of Current Ethical and Legal Issues. Journal of Business Ethics, 17(12), 1319-1323. http://dx.doi.org/10.1023/A:1005735506589

Institute of Management \& Administration (IOMA). (2000). What's in Store for HR Information Systems. HR Focus, 77(5), 10-11.

Kassim, N., Ramayah, T., \& Kurnia, S. (2012). Antecedents and Outcomes of Human Resource Information System (HRIS) Use. International Journal of Productivity and Performance Management, 61(6), 603-623. http://dx.doi.org/10.1108/17410401211249184

Katou, A., \& Budhwar, P. (2006). Human Resource Management Systems and Organisational Performance: A Test of a Mediating Model in the Greek Manufacturing Context. International Journal of Human Resource Management, 17(7), 1223-1253. http://dx.doi.org/10.1080/09585190600756525

Kavanagh, M., Gueutal, H., \& Tannenbaum, S. (1990). Human Resource Information Systems: Development and Application. Boston: PWS-Kent Publishing.

Kovach, K., \& Cathcart Jr., C. (1999). Human Resource Information Systems (HRIS): Providing Business with Rapid Data Access, Information Exchange and Strategic Advantage. Public Personnel Management, 28(2), 275-281. http://dx.doi.org/10.1177/009102609902800208

Kovach, K., Hughes, A., Fagan, P., \& Maggitti, P. (2002). Administrative and Strategic Advantages of HRIS. Employment Relations Today, 29(2), 43-48. http://dx.doi.org/10.1002/ert.10039

Laudon, K., \& Laudon, J. (2002). Management Information Systems: Managing the Digital Firm. New Jersey.

Lean, O., Zailani, S., Ramayah, T., \& Fernado, Y. (2009). Factors Influencing Intention to Use E-government Services among Citizens in Malaysia. International Journal of Information Management, 29(6), 458-475. http://dx.doi.org/10.1016/j.ijinfomgt.2009.03.012

Lederer, A. (1984). Planning and Developing a Human Resource Information System. The Personnel Administrator, 29(8), 27-39. http://dx.doi.org/10.1007/s12122-003-1001-6

Lengnick-Hall, M., \& Moritz, S. (2003). The Impact of e-HR on the Human Resource Management Function. Journal of Labor Research, 24(3), 365-379.

Lippert, S., \& Swiercz, P. (2005). Human Resource Information Systems (HRIS) and Technology Trust. Journal of Information Science, 31(5), 340-353. http://dx.doi.org/10.1177/0165551505055399

Martinsons, M. (1994). Benchmarking Human Resource Information Systems in Canada and Hong Kong. Information and Management, 26(6), 305-316. http://dx.doi.org/10.1016/0378-7206(94)90028-0

Ngai, E., \& Wat, F. (2006). Human Resource Information Systems: A Review and Empirical Analysis. Personnel Review, 35(3), 297-314. http://dx.doi.org/10.1108/00483480610656702 
Ramayah, T. (2010). The Role of Voluntariness in Distance Education Students Usage of a Course Website. Turkish Online Journal of Education Technology, 9(3), 96-105. http://dx.doi.org/10.1016/j.chb.2009.06.007

Ramayah, T., Rouibah, K., Muniandy, G., \& Rangel, G. (2009). A Decomposed Theory of Reasoned Action to Explain Intention to Use Internet Stock Trading among Malaysian Investors. Computers in Human Behaviour, 25(6), 1222-1230.

Reddick, C. (2009). Human Resource Information Systems in Texas City Governments: Scope and Perception of its Effectiveness. Public Personnel Management, $38(4), \quad$ 19-34. http://dx.doi.org/10.1177/009102600903800402

Rodriguez, J., \& Ventura, J. (2003). Human Resource Management Systems and Organisational Performance: An Analysis of the Spanish Manufucturing Industry. International Journal of Human Resource Management, 14(7), 1206-1226. http://dx.doi.org/10.1080/0958519032000114273

Sadri, J., \& Chatterjee, V. (2003). Building Organisational Character Through HRIS. International Journal of Human Resources Development and Management, 3(1), 84-98. http://dx.doi.org/10.1504/IJHRDM.2003.001048

Schaupp, L., Carter, L., \& McBride, M. (2010). E-file Adoption: A Study of US Taxpayers' Intentions. Computers in Human Behaviour, 26(4), 634-644. http://dx.doi.org/10.1016/j.chb.2009.12.017

Sheehan, C., Holland, P., \& De Cieri, H. (2006). Current Developments in HRM in Australian Organisations. Asia Pacific Journal of Human Resources, 44(2), 132-152. http://dx.doi.org/10.1177/1038411106066391

Tannenbaum, S. (1990). Human Resource Information Systems: User Group Implications. Journal of Systems Management, 41(1), 27-32.

Teo, T., Lim, G., \& Fedric, S. (2007). The Adoption and Diffussion of Human Resources Information Systems in Singapore. Asia Pacific Journal of Human Resources, 45(1), 44-62. http://dx.doi.org/10.1177/1038411107075402

Tetz, F. (1973). Evaluating Computer-based Human Resource Information Systems: Costs vs Benefits. Personnel Journal, 52, 451-455.

Toshani, I., Jerram, C., \& Hill, S. (2011). Exploring the Public Sector Adoption of HRIS. Industrial Management \& Data Systems, 111(3), 470-488. http://dx.doi.org/10.1108/02635571111118314

Troshani, I., Jerram, C., \& Gerrard, M. (2010). Exploring the Organisational Adoption of Human Resources Information Systems (HRIS) in the Australian Public Sector. Proceedings of thge 21st Australasian Conference on Information Systems (ACIS2010). Brisbane, Australia, December 1-3.

Venkatesh, V., \& Davis, F. D. (2000). Final version of Technology Acceptance Model (TAM). Management Science, 46(2), 186-204. http://dx.doi.org/10.1287/mnsc.46.2.186.11926

Wiblen, S., Grant, D., \& Dery, K. (2010). Transitioning to a New HRIS: The Reshaping of Human Resources and Information Technology Talent. Journal of Electronic Commerce Research, 11(4), 251-267.

Wille, E., \& Hammond, V. (1981). The Computer in Personnel Work. London: Institute of Personnel Management.

Yeh, C. (1997). Human Resource Information Systems: Implementation in Taiwan. Research \& Practice in Human Resource Management, 5(1), 57-72.

Yusoff, Y., Ramayah, T., \& Ibrahim, H. (2011). HR Roles and E-HRM: Some Initial Evidence from Malaysia. International Journal of Current Research, 3(2), 131-138.

\section{Copyrights}

Copyright for this article is retained by the author(s), with first publication rights granted to the journal.

This is an open-access article distributed under the terms and conditions of the Creative Commons Attribution license (http://creativecommons.org/licenses/by/3.0/). 